こで光を照射するとその反忘後のクロレラからの色素の抽出度は 照射時間の增加とともに減少した。しかもその抽出度の減少率は $\left(3^{\circ}\right.$ と $25^{\circ} \mathrm{C}$ の反忘の場合が同じであり $)$ 温度には無関係であっ た。またこの葉緑素の抽出度変化にともなうクロロフィールー とーbの抽出割合は前報に述べた $25^{\circ} \mathrm{C}$ の反応の場合と同様であ つた。

すなわち，照射時間約 20 分までは chl-a/chl-b の值は隇少 し, その後も抽出度は減少するが chl-a/chl-b の值は増加した。

以上の $3^{\circ} \mathrm{C}$ の有機酸鉄塩存在下に抢けるクロレラの明所反忘 乙前報の $25^{\circ} \mathrm{C}$ の同様の反応結果から, 抽出度の変化は反応温度 に影響のない $\mathrm{Fe}^{3+}$ の添加にともなう光化学反応に関係するもの であると結論しらる。

\section{2 全色素量（オパール法）}

各反応時閔の 終了後のクロレラの吸收带は 438, 468, $675 \mathrm{~m} \mu$ ご $25^{\circ} \mathrm{C}$ の反忘の場合と同様である。そして照射時間に対する吸 収带の变化も涩められなかった。しかし照射時間に対する全色素 濃度は $25^{\circ} \mathrm{C}$ の反忍の場合と異なり，いずれの吸収位置について も変化を亦さなかった。

与被ち，クロレラ中の $675 \mathrm{~m} \mu$ の全色素量は反忍温度に関係 すること坊汍められた。しかし，その色秦の抽出度は上述の 6.1 の結果に亦すように文芯温度の变化に影響を示さなかった。
したがって有機鉄塩の存在中明所で反応したクロレラ中の色素 の抽出度と, その全色素量との変化はたがいに関係のない別種の 反応であると結諭しうる。

\section{7 結}

\section{論}

1.クロレラ中の全色素量の抽出は中間で水洗することによっ て可能となった。

2. 有機酸鉄塩の水溶液中に懸濁したクロレラに光を照射与る と, そのクロレラ中の全色素量 [665 $\mathrm{m} \mu$ または 675 (オパール 法）の吸収带の夕]は $25^{\circ} \mathrm{C}$ の反応温度の場合には増加した。し かし他の吸収带では变化が認められなかった。

3. けれども反応温度が $3^{\circ} \mathrm{C}$ の場合には，いずれの吸収带に ついても濃度変化は認められなかった。

4. したがって反応温度に関係するものはクロレラ中の全色素 量だけであって，その他光の照射にともなう抽出度の減少やその 抽出液中の ch1-a/ch1-b の值の变化は反応温度に関係しなかつ た。

5. エタノール抽出液の場合, 抽出度の変化を示与ものは 438 $\mathrm{m} \mu$ の色素である。しかしクロレラ中の全色素の抽出液としては

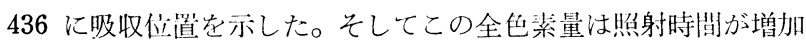
しても変化走示さなかった。

\title{
低 級脂肪酸によるアミノ酸のラセミ化
}

(昭和 34 年 3 月 12 日受理)

崎 浴 幾 雄 - 光 野 正: 樹†

$\mathrm{D}$-メチオニンを承酢酸と短時間加熱すると簡単にラセミ化するてとを認めたので，乙れをメチオニン誘導体について行なった

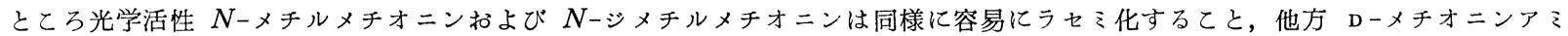
ドアセテートはラセミ化し難いてとを知った。またての方法を他の L系遊離アミノ酸について行なったところ，アスパラギン，口 イシン，フェニールアラニン，トリプトファンはメチオニンと同様に簡単にラセミ化するてと，グルタミン酸，ヒスチシン，イン ロイシンは一部ラセミ化するとと，扣よびシスチン，プロリン，チロシンはラセミ化し難いととがわかった。また Dーメチオニン は氷䣷酸以外にギ酸, プロピオン酸, $n$-酪酸でもラセミ化するととを認めた。

\section{1 緒言}

一般に光学活性の遊離アミノ酸はラセミ化し難く,すみやかに ラセミ化するために㳘温と压力を必要とする。またこのさい酸 による接触効果は小さいとされており，低級脂肪酸によるラセる 化についての報告はない。

著者らは $\mathrm{D}$-メチオニンのラセミ化法について研究した結果, 水酢酸と短時間加熱してラセミ化することを知った。この方法沈 メチオニンの誘導体抢よび他の光学活性アミノ唒夋に忍用し興味あ る結果を得たのでここに報告する。

Dーまたは Lーメチオニンのラセミ化法は従来いずれもとの誘導 体を合成して同時にラセミ化し，これを化学的または酵素的に加 水分解してラセミ系メチオニンとするものである1。Dーまたは L-

$\dagger$ 武田楽品工業株式会社光工場, 光市光井

1) V. du Vigneaud, C. E. Meyer, J. Biol. Chem. 98, 300 (1933); 立岡, 本庄, 宮崎, 薬誌 71, 1277 (1951); 田口, 石田, 第 76 回薬学会年 会講演 (1956) 福厥など.
メチオニンが塩酸, 硫酸などの強鉱酸ではラセミ化しないことは, 不活性体の光学分割のさいに得られるそれぞれの誘導体を，これ らの鉙酸によって加水分解生告場合ラセる体が得られないことに よって明らかである。

しかるに Dーメチオニンを䣷酸で处理したところつぎのことが わかった。

1. 水酢酸と 2 時間ゆるやかに堂沸与ると完全にラセミ化与 る。

2. 氷䣷酸と 7 時間沸騰水浴の中で加熱すると $[\alpha]_{\mathbf{D}}^{20}=-7.5^{\circ}$ のメチオニンの結晶が得られる。

3. 䣷酸の濃度を低くするとラセミ化しにくくなるが，50\%酢 酸で 2 時間煮沸しても約 $30 \%$ ラセ之化する(図 1 ) (次頁)。

4. 加熱時間とラセミ化の関係はほぼ直線的である(図 2 )（次 頁)。

5. 上記の方法でラセミ化するとラセそ化と同時に 1 部アセチ ル-DLーメチオニン, 無色柱状結晶, $\mathrm{mp} 110 \cup 112^{\circ} \mathrm{C}$ が得られる。 
つぎに光学活性 $N$-メチルメチオニン， $N$-ジメチルメチオニ ン它合成し,これについて同じ研究を行なった。これらは氷酢酸と 加熱すれば Dーメチオニンとまったく同様に容易にラセミ化す る。D-メチオニンアミド酶酸塩 $\left([\alpha]_{\mathrm{D}}^{20}=+15.5^{\circ}, \mathrm{mp} 102^{\circ} \sim 103^{\circ}\right.$ C) 泳酰酸と加熱しても施光度の変化はあまりないが, ラセミ体 が混合していると思わ机る白色羽毛状結晶, $\mathrm{mp} 132^{\circ} \sim 147^{\circ} \mathrm{C}$, $[\alpha]_{\mathrm{D}}^{20}=+15.0^{\circ}$ が得られる。

氷䣷酸によるラセミ化法がどの範囲に適用できるかを知るため に乎持らの光学活性 $\mathrm{L}$ 系アミノ酸について行なった結果を表 1 に 示す。いずれも約 3〜10 倍量の水酶酸（加熱時におのおのアミ， 酸が容易に溶解しうる量）とゆるやかに 2 時間煮沸したのち減压 乾固し，残留物を適宜の方法で再結晶して施光度を測定した。表 1 に明らかなようにアスパラギン, ロイシン, フェニルアラニン, トリプトファンはメチオニンと同様に容易にラセミ化する。グル タミン豁，ヒスチジン，イソロイシンは部分的にラセミ化され， シスチン，プロリン，チロシンはほとえどラセミ化しない。

$\mathrm{D}$ ーメチオニンについては酶胵以外の低級脂肪酸による加熱処

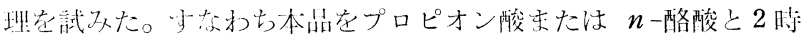

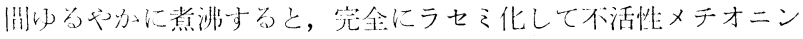

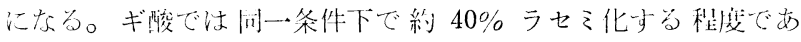
\%。

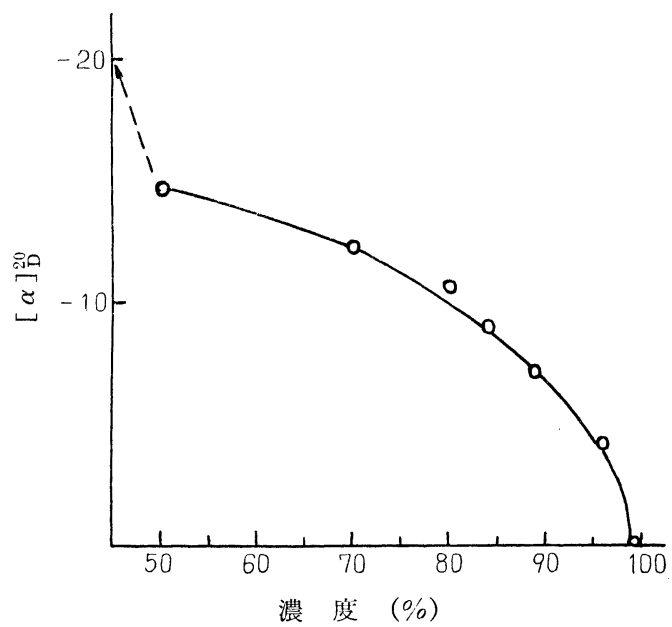

図 1 酢酸の濃度とラ七之化の関係

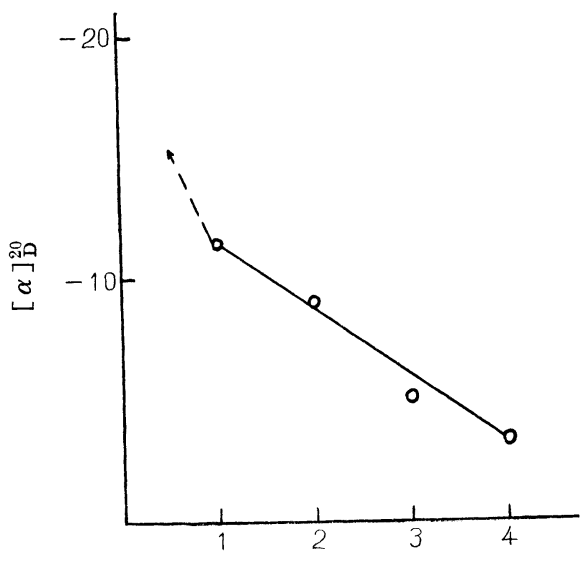

時 間 $(\mathrm{hr})$

図 2 加熱時間とラセミ化の関係（84\% 酢酸）

\begin{tabular}{|c|c|c|c|}
\hline ア 乏, 酸 & 加熱前 & 加熱後 & 測定条件 \\
\hline アスパラギン & +30.5 & 0 & $c=2 \%, \quad \mathrm{~N} \mathrm{HCl}$ \\
\hline ス チ ン & -204.2 & -204.2 & $1.4 \%$ \\
\hline グルタミン酸 & +32.0 & +25.6 & $2.5 \%, \mathrm{~N} \mathrm{HCl}$ \\
\hline ヒスチジン & -36.0 & -27.5 & $2 \%, \quad \mathrm{H}_{2} \mathrm{O}$ \\
\hline イソロイシン & +35.5 & +21.2 & $8 \%, 6 \mathrm{~N} \mathrm{HCl}$ \\
\hline ロ イ シ ン & -10.4 & 0 & $4 \%, \mathrm{H}_{2} \mathrm{O}$ \\
\hline ×チオ $=$ ン & +20.0 & 0 & $4 \%, 3 \mathrm{~N} \mathrm{HCl}$ \\
\hline$フ_{ェ}$ ニルアラニン & -34.0 & 0 & $1.5 \%, \mathrm{H}_{2} \mathrm{O}$ \\
\hline プロリン & -84.0 & -80.0 & $4 \%, " 1$ \\
\hline トリプトファン & -31.68 & 0 & $1 \%, " \prime$ \\
\hline チ ロ シ ン & -11.5 & -11.0 & $9 \%, 3 \mathrm{~N} \mathrm{HCl}$ \\
\hline 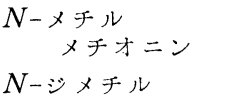 & -38.4 & 0 & $2.5 \%$ \\
\hline $\begin{array}{c}\text { メチオニン } \\
\text { メチオニンアミド } \\
\text { 酢酸睢 }\end{array}$ & $\begin{array}{l}-69.0 \\
+15.5\end{array}$ & +15.0 & $\begin{array}{l}1.33 \%, \quad " \prime \\
3.33 \%, \quad \mathrm{H}_{2} \mathrm{O}\end{array}$ \\
\hline
\end{tabular}

2 考察

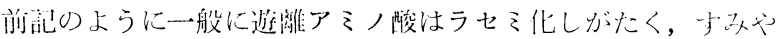

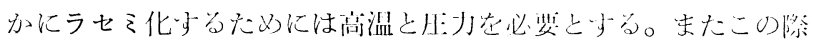

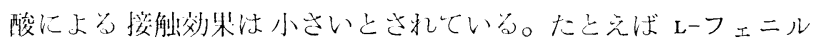

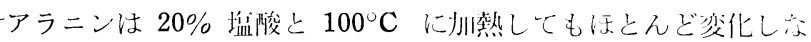

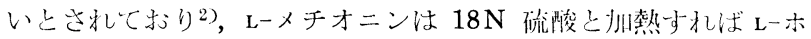
モシスチンとな\%が，この際 1 部ラセミ化したものが得られる刑

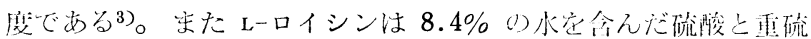

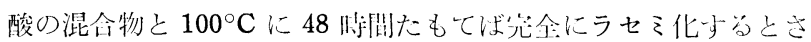
れており がラセる化するとされている5っ。かるに上就のようにこれらの 遊離アるノ酸它低級脂肪酸と 2 時间ゆるやかに省沸与る上, 容易 にラセミ化が行なわ秃るということは，この反忘が酸による単な

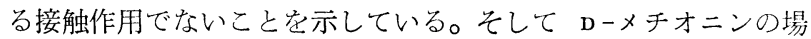
合に認めたアセチル体副生の事実は, 中間体としてアズラクトン の生成を考えることによって説明されるアるノ酸のアシル化の間 に起るラセミ化とするのが妥当であろう。プロリンがラセミ化し ないのはアズラクトンを形成し 得ないからである。N-メチルお よび $N$-ジメチルメチオニンのラセミ化はアズラクトン中問体で は説明することはできないが，㧍とらくアミノ基上の陽電荷の消 失が酸によるラセミ化を促進したものと考えられる。 Dーメチ才 ニンアミド酢酸榼がラセミ化しないのはアズラクトンの形成がで きないためと考える。

\section{3 実 験 の 部*1}

\subsection{DL-メチオニン}

$\mathrm{D}$ ーメチオニン $5 \mathrm{~g}$ 它水酢酸 $15 \mathrm{cc}$ ともに 2 時胆以るやかに

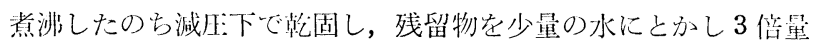
つエタノ一ルを加えると絬晶が析出する。水一エタノールから再 結晶。光沢ある無色リン片状結晶。 $\mathrm{mp} 270^{\circ} \sim 272^{\circ} \mathrm{C}$ (分解)。収 量 $3.5 \mathrm{~g}(70 \%)$ 。 $[\alpha]_{\mathrm{D}}^{20}=0$ 。

2）赤堀, 水泉, “蛋白䆩化学” 1, p. 439 (1954) 共立出版.

3) V. du Vigneaud, W. I. Patterson, J. Biol. Chem. 109, 97 (1935).

4) D. Rittenberg, et al., ibid. 125, 1 (1938).

5) T. Wieland, D. Wolfgang, Ber. 17, 34 (1944) ほか.

*1 mp はいずれも未補正である. 
分析值 C $40.52 \%, \mathrm{H} 7.48 \%$

$\mathrm{C}_{5} \mathrm{H}_{11} \mathrm{O}_{2} \mathrm{NS}$ としての計算值 C $40.25 \%, \mathrm{H} 7.43 \%$ なお 2 時問煮沸後の水酶酸溶液をとのまま 1 夜放冷して析出与 る結晶芯水一エタノ一ルから再絬晶与秃ば DL-メチオニン $2 \mathrm{~g}$ が 得られる。

\section{2 アセチル-DL-メチオニン}

3.1 で得ら机る最初のエタノール水母液䘮減上:乾固し残留物を

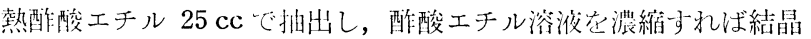

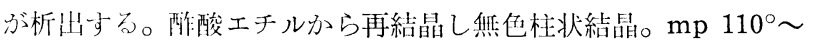
$112^{\circ} \mathrm{C}_{\circ}$ 収量 $1.0 \mathrm{~g}(20 \%)$ 。ラセそ型アセチルメチオニンと混融 して融点降下を示さない。

\section{3 酢酸の濃度とラセミ化の関係（図 1)}

Dーメチオニン $5 \mathrm{~g}$ 学各蕽度の酢酸 $15 \mathrm{cc}$ とともに 2 時間ゆる やかに竟沜したのち減压乾固し残留物它温水に溶解しごく少量の 活性炭を加えて口過後エタノール3 倍量を㞦えて絬鼠壱析山させ る。

\begin{tabular}{|c|c|c|c|}
\hline & 表 & 2 & \\
\hline $\begin{array}{c}\text { 酢酸の濃度 } \\
(\%)\end{array}$ & $\begin{array}{c}\text { 囯收メチオニン } \\
(\mathrm{g})\end{array}$ & $\begin{array}{c}\text { 们収率 } \\
(\%)\end{array}$ & $\begin{array}{c}[\alpha]]_{\mathrm{D}}^{20} \\
(c=4 \%, 3 \mathrm{~N} \mathrm{HCl})\end{array}$ \\
\hline 99.5 & 3.75 & 72 & 0 \\
\hline 96 & 3.90 & 78 & -4.25 \\
\hline 89 & 4.45 & 89 & -7.25 \\
\hline 80 & 4.65 & 93 & -10.75 \\
\hline 70 & 4.75 & 95 & -12.25 \\
\hline 50 & 4.90 & 98 & -14.65 \\
\hline
\end{tabular}

\section{4 加熱時間とラセミ化の関係（図 2 )}

Dーメチオニン $5 \mathrm{~g}$ 在 $84 \%$ 酢酸 $15 \mathrm{cc}$ とともに 1〜4 㬨间以

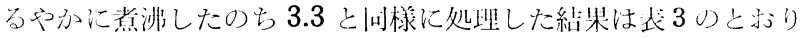
である。

\begin{tabular}{cccc}
\multicolumn{5}{c}{$\begin{array}{c}\text { 表 } \\
\text { 加熱時間 } \\
(\mathrm{hr})\end{array}$} & $\begin{array}{c}\text { 回收メチオニン } \\
(\mathrm{g})\end{array}$ & $\begin{array}{c}\text { 回収率 } \\
(\%)\end{array}$ & $\begin{array}{c}{[\alpha]_{\mathrm{D}}^{20}} \\
1\end{array}$ & 4.45 & 89 & -11.5 \\
2 & 4.35 & 87 & -9.0 \\
3 & 4.05 & 81 & -5.0 \\
4 & 3.90 & 78 & -3.5
\end{tabular}

\section{5 加熱温度の影響}

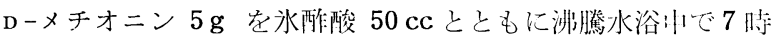

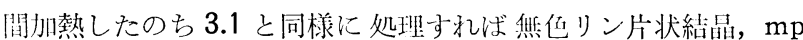
$271^{\circ} \sim 273^{\circ} \mathrm{C}$ (分解)， $[\alpha]_{\mathrm{D}}^{20}=-7.5^{\circ}$ ○) チオニンが得られる。

\section{$3.6 N$-メチル-DL-メチオニン}

泉屋の方法6)にしたがい ムー $\gamma$ ーメチルチオ酪酸をメチルアミンと处堽して得られる $N$-メ チルメチオニン*2(白色小板状結晶, $\mathrm{mp} 239^{\circ} \mathrm{C}$ (分解), $[\alpha]_{\mathrm{D}}^{20}$ $\left.38.4^{\circ}(c 2.5 \%, 3 \mathrm{~N} \mathrm{HCl})\right) 2 \mathrm{~g}$ を水䣫酸 $10 \mathrm{cc}$ とともに 2 㭙阽 河当やかに煮沸したのち減压乾固し，残留物を水一エタノ一ルか ら再結晶与る。無他板状絬晶， mp $230^{\circ} \sim 232^{\circ} \mathrm{C}$, 収量 $1.5 \mathrm{~g}$ $(75 \%)$ 。

\section{7}

a ）光学活性 $\boldsymbol{N}$-ジメチルーメチオニン*2: 3.6 と间救 L-メチ

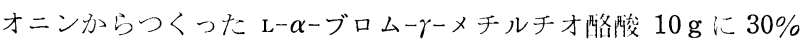

6) 家姑, 日化 72, 28 (1951)

*2 いずれも $\mathrm{D}$ 系であると推旅される。
ジメチルアミン水溶液 $150 \mathrm{cc}$ を加えて 24 時間水窒内沈放置後 $60^{\circ} \mathrm{C}$ に 1 時間たもつ。隇压乾固して残留物をクロロホルム 150 cc に加熱溶解し, 少量の活性炭を加えて口過する。口液它約 50 cc に濃縮し，アセトン約 $30 \mathrm{cc}$ 名加えて析出する結晶を口取し， クロロホルムーアセトンから再結晶する。白色板状結晶, mp $185^{\circ}$ $\sim 186^{\circ} \mathrm{C}_{\circ}$ 收量 $3.2 \mathrm{~g}(38.5 \%) 。[\alpha]_{\mathrm{D}}^{20}=-69.0^{\circ}(c=1.33 \%$, $3 \mathrm{~N} \mathrm{HCl)。}$

分析值 C $47.30 \%, \mathrm{H} 8.54 \%, \mathrm{~N} 7.55 \%, \mathrm{~S} 18.51 \%$ $\mathrm{C}_{7} \mathrm{H}_{15} \mathrm{O}_{2} \mathrm{NS}$ としての

計算值 C $47.44 \% ， \mathrm{H} 8.53 \% ， \mathrm{~N} 7.90 \% ， \mathrm{~S} 18.09 \%$

b ） $\boldsymbol{N}$-ジメチル-DL-メチオニン：上記光学活性 $N$-ジメチルー メチオニン $2.5 \mathrm{~g}$ 学水莋酸 $10 \mathrm{cc}$ とともに 2 㭙間ゆるやかに堂 沸したのち，減止乾国し残留物をメタノールーアセトンから再結 晶する。無色板状絬晶, $\mathrm{mp} 178^{\circ} \mathrm{C}$, 收量 $2.2 \mathrm{~g}$ 。

\section{8 メチオンアミド酢酸塩}

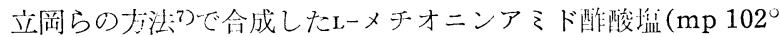
$\left.\sim 103^{\circ} \mathrm{C}, \quad[\alpha]_{\mathrm{D}}^{20}=+15.5^{\circ}\left(c 3.33 \%, \mathrm{H}_{2} \mathrm{O}\right)\right) 5 \mathrm{~g}$ 觉水䣷酸 20

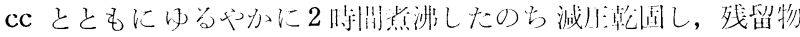

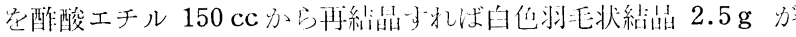
得ら柇\%。mp $132^{\circ} \sim 147^{\circ} \mathrm{C},[\alpha]_{\mathrm{D}}^{20}=+15.0\left(c \quad 3.33 \%, \mathrm{H}_{2} \mathrm{O}\right)$ 。

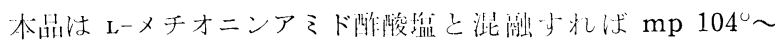

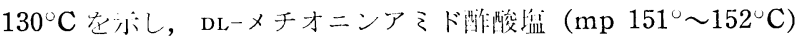
と混融与扎ば $\mathrm{mp} 130^{\circ} \sim 149^{\circ} \mathrm{C}$ 在示す。

\subsection{DL-ロイシン}

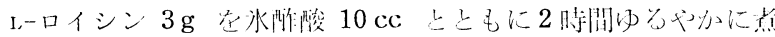

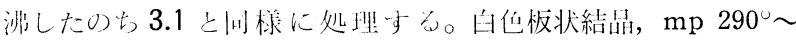
$293^{\circ} \mathrm{C}_{\text {。 }}$ 収量 $1.2 \mathrm{~g}(40 \%)$ 。

$3.10 \mathrm{DL}^{-}$フェニルアラニン

$\mathrm{L}$ ーフェニルアラニン $3 \mathrm{~g}$ 在 3.9 と同様に処理し約 $50 \mathrm{cc}$ の熱 晹から再結晶与年。光沢ある白任りン片状結唱。 $\mathrm{mp} 260^{\circ} \sim 264^{\circ}$ $\mathrm{C}$, 収量 $1.8 \mathrm{~g}(60 \%)$ 。

\subsection{DL-アスパラギン}

L-アスパラギン $3 \mathrm{~g}$ を 3.9 と同栐に处理し熱湯から再結晶す る。無他プリズム状結晶， $\mathrm{mp} 223^{\circ} \sim 224^{\circ} \mathrm{C}$ (分解)。収量 $1.0 \mathrm{~g}$ $(33 \%)$ 。

\subsection{DL-トリプトファン}

Lートリプトファン $3 \mathrm{~g}$ を水酶酸 $30 \mathrm{cc}$ とともに州熱処理し希 アルコールから再絬晶与并。白他羽毛状絬品， $\mathrm{mp} 270^{\circ} \sim 278^{\circ} \mathrm{C}$, 收显 $2 \mathrm{~g}(66 \%)$ 。

\subsection{3 イソロイシン}

Lーイソロイシン $3 \mathrm{~g}$ を 3.9 と同様に処理し約 $50 \mathrm{cc}$ の熱湯か ら再絬昆し, 白色りン片状絬品, $\mathrm{mp} 270^{\circ} \sim 272^{\circ} \mathrm{C}$ (封管中)。収 星 $2 \mathrm{~g}(66 \%)$ 。 $[\alpha]_{\mathrm{D}}^{20}=+21.2^{\circ}(c=8 \%, 6 \mathrm{~N} \mathrm{HCl})$ 。

\subsection{4 グルタミン酸}

Lーグルタミン酸 $3 \mathrm{~g}$ を 3.9 と间様に処理し約 $30 \mathrm{cc}$ の熱湯か ら再絬品与る。且色小柱状絬奛, $\mathrm{mp} 205^{\circ} \sim 208^{\circ} \mathrm{C}$ (分解), 収量 $1.2 \mathrm{~g}(40 \%)$ 。 $[\alpha]_{\mathrm{D}}^{20}=+25.6^{\circ}(c=2.5 \%, 6 \mathrm{~N} \mathrm{HCl})$ 。

\subsection{5 ヒスチジン}

Lーヒスチジン $3 \mathrm{~g}$ を 3.12 と同㥞に処理して希アルコールから 再絬晶する。白色小板状結晶, $\mathrm{mp} 270^{\circ} \sim 273^{\circ} \mathrm{C}$ (分解)。収量 $2.5 \mathrm{~g}(83 \%)$ 。 $[\alpha]_{\mathrm{D}}^{20}=-27.5^{\circ}\left(c=2 \%, \mathrm{H}_{2} \mathrm{O}\right)$ 。

7) 立阔，本庄，槳誌 73，355，357 (1953). 


\subsection{6 シスチン}

レーシスチン $3 \mathrm{~g}$ を 3.9 と同様に処理して熱湯から再結晶する。

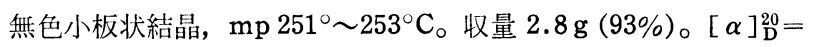
$204.2^{\circ}(c=1.4 \%, 1 \mathrm{~N} \mathrm{HCl})$ 。

\subsection{7 チロシン}

L-チロシン $3 \mathrm{~g}$ を 3.9 と同様に処理して熱湯から再結晶する。 針状結晶, $\mathrm{mp} 310^{\circ} \mathrm{C}$ 付近(分解)。收量 $2.7 \mathrm{~g}(90 \%) 。[\alpha]_{\mathrm{D}}^{20}=$ $-11.0^{\circ}$ 。

\subsection{8 プロリン}

Lープロリン $3 \mathrm{~g}$ を 3.9 と同様に処理して無水エタノールから 2 [四再結晶与る。白色小柱状結晶。 $\mathrm{mp} 213^{\circ} \sim 218^{\circ} \mathrm{C}$ (発泡)。収 量 $1.1 \mathrm{~g}(36 \%)$ 。 $[\alpha]_{\mathrm{D}}^{20}=-80.0^{\circ}\left(c=4 \%, \mathrm{H}_{2} \mathrm{O}\right)$ 。

\subsection{9 プロピオン酸によるラセミ化}

$\mathrm{D}$ ーメチオニン. $3 \mathrm{~g}$ をプロピオン酸 $45 \mathrm{cc}$ とともに 2 時間ゆ るやかに劣沸したのち泠却し，酶酸エチル $45 \mathrm{cc}$ を加えて析出 する絬晶を口取して水一エタノールから再絬晶すれば光沢ある無 色リン片状結晶, $\mathrm{mp} 270^{\circ} \sim 272^{\circ} \mathrm{C}$ (分解), $2.4 \mathrm{~g}$ が得られる。
$[\alpha]_{\mathrm{D}}^{20}=0$ 。

\section{$3.20 \boldsymbol{n}$-酪酸によるラセミ化}

$\mathrm{D}$ 一メチオニン $3 \mathrm{~g}$ を $n$-酪酸 $40 \mathrm{cc}$ とともに 3.19 と同様に 処理してラセミ系メチオニン $2.6 \mathrm{~g}$ をうる。

\subsection{1 ギ酸によるラセミ化}

$\mathrm{D}$ ーメチオニン $3 \mathrm{~g}$ をギ酸（約 $80 \%$ ） $10 \mathrm{cc}$ とともに 2 時間ゆ るやかに煮沸したのち減目乾固し残留物を水一エタノールから 2 回再結晶すれば 1 部ラセミ化された $\mathrm{D}$ ーメチオニン, $\mathrm{mp} 270^{\circ}$ 人 $273^{\circ} \mathrm{C}, 1.0 \mathrm{~g}(33 \%)$ が得られる。 $[\alpha]_{\mathrm{D}}^{20}=-11.4^{\circ}(c=4 \%, 3 \mathrm{~N}$ $\mathrm{HCl}$ )。

終りにのぞみ本研究に終始御指導御鞭撻を賜わった当社研究所 長桑田 智博士，本社開発部長田中福寿博士，メチオニンアミド 酢酸塩を恵与していただいた研究所第 2 部長立岡未雄博士に謹謝 します。また元素分析定実施していただいた研究所分析室の方々 に潹謝します。な打本研究を発表する機会を与えられた倉林工場 長に厚く御礼申します。

\section{一酸化宸素の高压反応の研究 $(\text { 第 } 5 \sim 7 \text { 報 })^{1)}$}

(昭和 34 年 3 月 16 日受理)

堀家茂樹十

\section{（第 5 報） アゾ化合物と一酸化炭素の反応（その 2)}

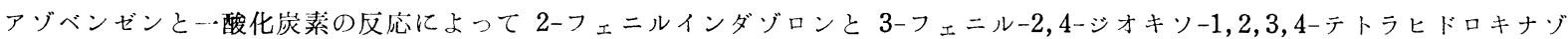
リンを生成する反応，拉よび生成したキナゾリンの加水分解によってアントラニル酸を生成する反応の応用性を検誩した結果につ いて述べる。
}

コバルトカルボニルあるいは鉄カルボニルを触媒とするアゾベ ンゼンと一酸化炭素の反忍により 2-フェニルインダゾロンおよ び 3-フェニル-2, 4-ジオキソ-1, 2, 3, 4-テトラヒドロキナゾリン を好收率に生成与る反志について第 4 報りに述べた。

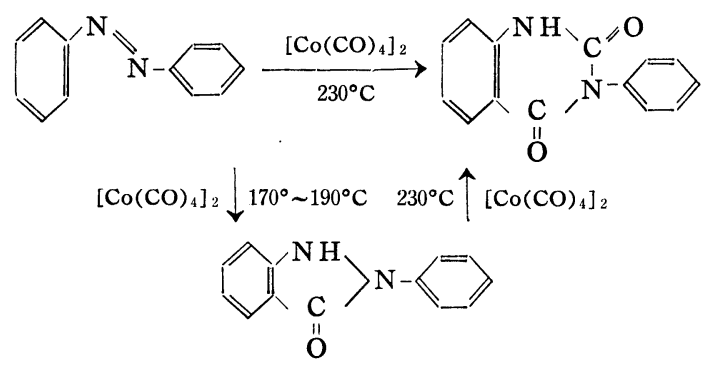

この種反応はこれまでに見られない新らしい型の一酸化炭素の 反灾であって，本反灾の機構を詳細に与ることは学術上の興味が ありまたとの応用性を知ることは実用上に興味が持たれる。こ のことは生成するインダゾロン化合物和よびキナゾリン化合物が 染料, 合成化学薬品, 合成樹脂材料ないしはその中間体材料とし て有用な化合物を与えるであろうことが予想されるからである。 本報にはこれらの目的で種々の置換基を有するアゾ化合物およ

$\dagger$ 大阪大学産業科学研究所, 堺市北花田町

1）前報（第 4 報)，堀家，日化 79，499 (1958)。
び関連化合物と一酸化炭素の反応について 検討した結果を述べ る。

表 1 および裴 2 に見られるように，置換基を持つアゾベンゼン からのインダゾロン化合物打よびキナゾリン化合物の生成率は必 ずしも良好とはいえない。しかしベンゼン核の一方のオルト位あ るいはパラ位に電子放山性置換基がある場合，一酸化炭素による 閉環反応は置換基のあるベンゼン核側にのみ選択的に起り，電子 吸引性置換基のある埸合，予期の反忍がほとんど進行しないこと は興味ある結果である。このことはおそらく“ $\mathrm{N}=\mathrm{N} ”$ 結合に対 して最初の一酸化炭絜が反応寸る際の “ $\mathrm{N}=\mathrm{N} ”$ 結合の塩基性度 がこの反応の難易を支配し，かつ両窒素原子のうち，より塩基性 度の大きい方，与なわちパラ位に電子放出性置換基のある場合で

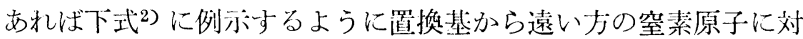
して最初の一酸化炭甚が絬合して行くのであろうことを示してい ๖。

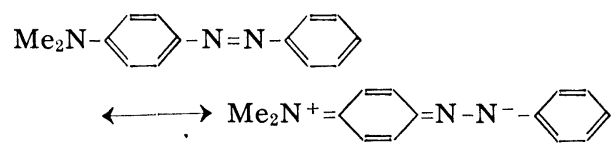

キナゾリンが希薄アルカリ水溶液によって容易に加水分解され て好収率にアントラニル酸を生成することは第 4 報に述べた。

2) H. H. Jaffé, R. W. Gardner, J. Am. Chem. Soc. 80, 319 (1958). 